Rev. Biol. Trop., 47(4): 1051-1059, 1999

www.ucr.ac.cr www.ots.ac.cr www.ots.duke.edu

\title{
Chromosomes of Cichlasoma istlanum (Perciformes: Cichlidae) and karyotype comparison of two presumed subspecies
}

\author{
Manuel Uribe-Alcocer, Carlos Téllez-Vargas and Píndaro Díaz-Jaimes
}

Instituto de Ciencias del Mar y Limnología, UNAM. Apdo. Postal 70-305, México, D.F. 10810, México. FAX: ++ (525) 6160748 , e-mail: muribe@ mar.icmyl.unam.mx

Received 12-II-1999. Corrected 16-IV-1999. Accepted 11-V-1999.

\begin{abstract}
Cichlasoma istlanum (Jordan \& Snyder, 1900) is a freshwater cichlid from the Balsas river province in the Pacific Basin. Two subspecies: $C$. istlana istlana, from the Ixtla river in the state of Morelos, Mexico, and C. istlana fusca, from the Huámito river near the town of La Huacana, in the state of Michoacán, were named half a century ago on the basis of meristic characters. In this work, the karyotype of the species was established by conventional and G-banding cytogenetic procedures and a comparative analysis of karyotypes from the two populations, previously proposed as subspecies, was performed. Ten females were collected in the Amacuzac river, and nine specimens (two females), were collected in the Huámito river. Based on the count of 264 mitotic fields of the former and 203 of the latter, the modal number of $2 n=48$ was established in every sample and considered as the diploid number of both populations. The karyotype analysis was based on ten karyotypes prepared from Morelos and eight from Michoacán, which included three from females and five from males. The chromosome formula thus established was of $8 \mathrm{sm}+40$ stt. The G-banding pattern was similar in both populations and the comparison of the mean lengths of the chromosome pairs did not reveal statistically significant differences between both populations. The presence of a practically identical karyotype does not support the subspecific division. The morphometric analyses made by other authors, which detected overlapping in the characters that were proposed as distinctive of the two subspecies, agree with the results of this study: not enough divergence has been found to substantiate the subdivision of $C$. istlanum. The lack of population divergence might have been brought about by an abated geographic isolation caused by gene flow among contiguous populations along their continuous distribution in the Balsas Basin regions, by the relatively small divergence time since their distribution in these regions, and/or, less probably, by a recent historical replacement of one population by the other. The absence of karyotype differences might also be attributed to characteristics inherent to the genome organization in the genus Cichlasoma still to be identified and understood.
\end{abstract}

Key words: Cichlasoma istlanum, cytogenetics, chromosomes, G-bands, Cichlidae, Balsas River.

The family Cichlidae is represented in Mexico by the two autochthonous genera: Petenia Günther 1862 and Cichlasoma Swainson 1839, and by the introduced Tilapia Smith 1840 and Oreochromis Günther 1889.
The genus Cichlasoma is found only in the New World where it comprises approximately 49 species, whereas the genus Petenia includes only one (Nelson 1994). These fishes have been the subject of several regional studies 
dealing with their taxonomy (Vega-Bravo 1973, Arredondo-Figueroa \& Guzmán-Arroyo 1986, Mejía-Mójica 1997), genetics (UribeAlcocer et al. 1992), feeding habits (TrujilloJiménez 1995), ecology (Sánchez-Salazar 1984), reproduction and growth (MartínezPalacios \& Ross 1992, Contreras-McBeath 1997, Cruz-Gómez \& Rodríguez-Varela 1997, Luna-Figueroa \& Figueroa-Torres 1997), parasitism (Lamothe-Argumedo \& AguirreMacedo 1991, García 1993), and potential for aquaculture (Martínez-Palacios et al. 1993).

Cichlasoma istlanum (Jordan \& Snyder, 1900) is a freshwater cichlid from the Balsas River province in the Pacific Basin. It has been collected from the high river sources to the mouth river. Its distribution area includes also the small basins of the Armería river in the states of Colima and Jalisco, and some other small basins of the state of Guerrero, such as those of the Nexapa, Papagayo, and Coyuca rivers (De Buen 1946, Miller 1966, Alvarez del Villar 1970, 1972a, b, 1977). Recent reports have shown its drastic displacement by the exotic cichlid $C$. nigrofasciatum (ContrerasMcBeath 1997).

De Buen (1946) based on differences of the fin-rays formulas and on the number of spines divided the species $C$. istlanum into two subspecies: $C$. istlana istlana, from the Ixtla river in the state of Morelos, and $C$. istlana fusca, from the Huámito river near the town of La Huacana, in the state of Michoacán.

The karyotype might characterize a species through the determination of the number, size and structure of its chromosomes. Although in vertebrates it constitutes a particularly stable feature because it does not seem to be subject to direct selective pressures, chromosome variability has been shown in some species through the detection of polymorphisms in the chromosome diploid number, like in Noturus albater Taylor 1969 (LeGrande 1981), Gymnotus carapo L. 1758 (Foresti et al. 1984), Gobius niger L. 1758 (Vitturi \& Catalano 1989), Gobius paganellus L. 1758 (Amores et al. 1990) and in the cichlid C. friedrichsthali (Heckel, 1840) (Salas \&
Boza 1991) or by the presence of supernumerary chromosomes, like in Prochilodus scrofa Steindachner 1881 (Pauls \& Bertollo 1983) and in the cichlid Gymnogeophagus balzanii (Perugia 1891) (Feldberg \& Bertollo 1984). These antecedents justify the search of chromosome differences that might be coincident with the spatial separation of the subspecies proposed by De Buen (1946).

The purpose of this study was to establish the karyotype and the G-banding pattern of $C$. istlanum, obtained from organisms of the same regions where De Buen (1946) collected the samples that led him to establish the subspecific division of the species, and to compare the chromosome diploid number, the morphology, relative size and banding patterns of the chromosomes from both samples, in order to provide arguments to verify or deny the subdivision of the species.

\section{MATERIALS AND METHODS}

Ten females were collected in the Amacuzac river, near the town of $\mathrm{La}$ Fundición, in the state of Morelos, Mexico, $\left(18.52^{\circ} \mathrm{N}\right.$ and $\left.99.22^{\circ} \mathrm{W}\right)$ and nine organisms: two females and seven males in the Huámito river near the town of La Huacana, in the state of Michoacán $\left(18.95^{\circ} \mathrm{N}\right.$ and $\left.101.87^{\circ} \mathrm{W}\right)$. These sample sizes fall within the range used in several cytogenetic studies, due to the karyotype stability generally found.

The cytogenetic methods followed to obtain the mitotic fields have been described by Uribe-Alcocer et al. (1983) and MaldonadoMonroy et al. (1985). Briefly, they consist of a pretreatment with calcium chloride and colchicine, gentle scraping of the gill epithelium followed by a hypotonic shock, fixation in a methanol-acetic acid solution, air slide drying and Giemsa staining. The method of Levan et al. (1964), based on the centromere position, assessed in this work through the determination of the centromeric index (short arm length $(p) /$ total chromosome length $(p+q)$ ), was followed to classify chromosomes. The G-banding 
patterns were obtained by incubation of the slides in $2 \mathrm{xSSC}$ at $60^{\circ} \mathrm{C}$ for $2 \mathrm{hr}$, followed with digestion with a mixture of trypsin $0.03 \%$ and Giemsa stain $3.3 \%$ in buffer phosphate $\mathrm{pH}$ 7.2 (Ruiz-Carús, 1995).

\section{RESULTS}

Chromosomes of 467 mitotic fields, derived from both populations, were counted to identify the modal number, 48 , which was considered as the diploid number of the species. Numbers under the mode were considered as chromosome losses during the cytogenetic technique rather than aneuploidies, due to the decreasing frequencies of chromosome numbers below the modal diploid num- ber in all specimens studied and to the lack of high frequencies indicative of a different chromosome number in any particular specimen.

Eighteen mitotic fields were studied to determine the karyotype of the species. In both samples it was composed by four submetacentrics pairs (sm), and 20 subtelo-acrocentric (stt) chromosome pairs. The chromosome formula derived from both samples was $8 \mathrm{sm}+40$ stt. The fundamental number found (number of chromosome arms: two for submetacentrics and one for subtelocentric and acrocentric chromosomes) was 56. Figs. 1 and 2 show the chromosome groups as well as their G-banding pattern. A digitally composed karyotype, which shows an element of each population for every chromosome pair, is depicted in Fig. 3.

Uribe Alcocer et al.

"Chromosomes of

Cichlasoma..."

Fig. 1

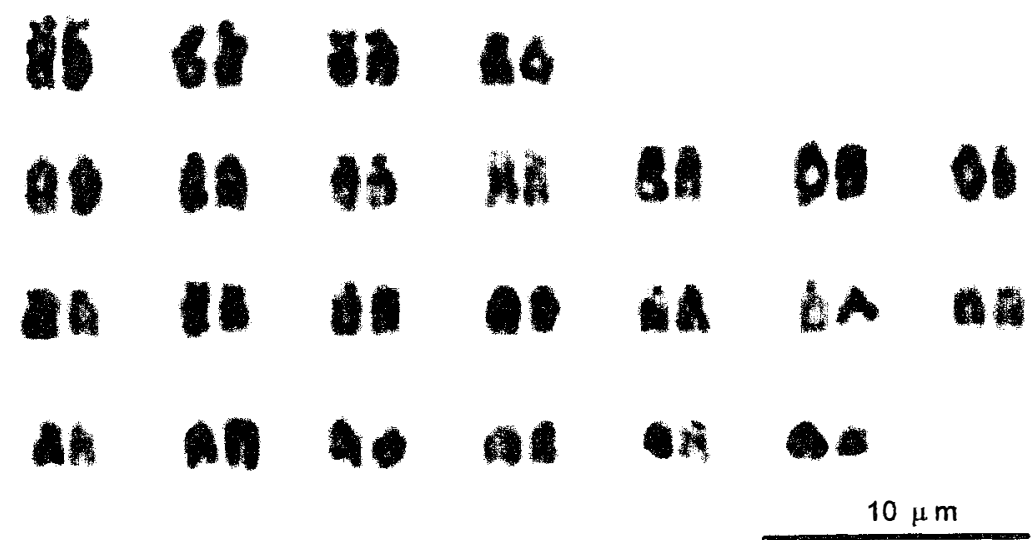

Fig. 1. G-banded karyotype of $C$. istlanum from Morelos sample. The upper row shows the submetacentric chromosomes, other rows, subtelocentric and acrocentric chromosomes.

Uribe Alcocer et al.

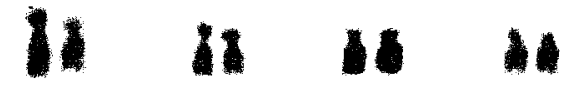

"Chromosome of

Cichlasoma ..."

Fig. 2

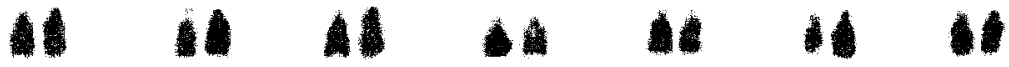

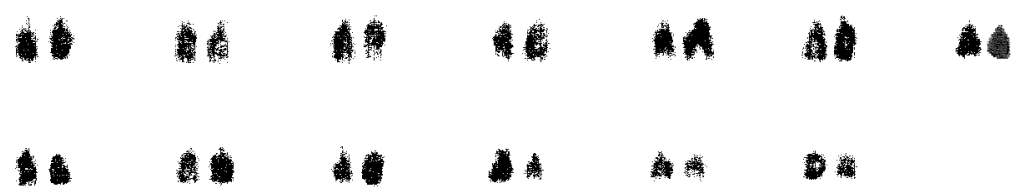

$10 \mu \mathrm{m}$

Fig. 2. G-banded karyotype of $C$. istlanum from the sample of Michoacán. 


\section{Uribe Alcocer et al \\ "Chromosomes of \\ Cichlasoma...."}

Fig. 3

\section{if 61 il at}

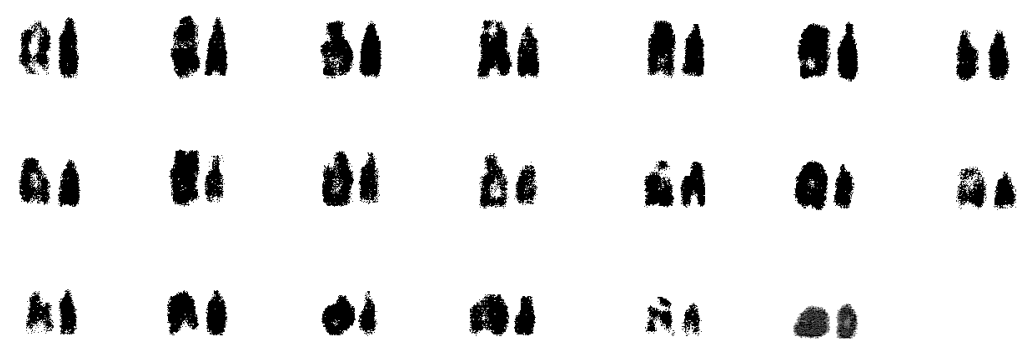

Fig. 3. Digitally composed karyotype of $C$. istlanum, which shows at left and at right of every chromosome pair an element of the Morelos and of the Michoacán populations respectively. The chromosomes of the latter have been artificially enlarged to the approximate same size of its counterpart to emphasize the correspondence of the G-bands.

Mean relative length of the chromosome pairs corresponding to both samples and their standard deviations are shown in Table 1. They were derived from the measurements of ten karyotypes from the sample of the state of Morelos and eight from the state of Michoacán. No dependence among the chromosome diploid number counts and the specimens analyzed nor the collecting sites was found (Contingency table $\mathrm{p}>0.05$ ). Data corresponding to chromosome and arm lengths were assayed for goodness of fit to a normal distribution and no statistical differences were found (Shapiro Wilk W $\mathrm{p}>0.05$ ). Similarly no differences were found between the natural logarithms of the standardized whole length chromosome $(p+q)$ of every pair, nor between the short (p) and long arms (q) of the four biarmed chromosome pairs of both populations (Two-way ANOVA $\mathrm{p}>0.05$ ).

Consistently with the lack of reports on sex chromosomes in all other cichlid species studied, heteromorphic chromosome elements, indicative of differentiated sex-chromosomes, were not detected in the sample of the Huámito river, the only site in which both sexes were represented.

TABLE 1

Mean relative lengths of the chromosome pairs of the karyotypes of $\mathrm{C}$. istlanum from the Amacuzac river (Morelos) and the Huámito river (Michoacán)

\begin{tabular}{cccccc}
\multicolumn{2}{c}{ Morelos population } & \multicolumn{3}{c}{ Michoacan population } \\
$\begin{array}{c}\text { Chromosome } \\
\text { pairs }\end{array}$ & $\begin{array}{c}\text { Relative } \pm \text { standard } \\
\text { length deviation }\end{array}$ & $\begin{array}{c}\text { Centromeric } \\
\text { index }_{(1)}\end{array}$ & $\begin{array}{c}\text { Relative } \pm \text { standard } \\
\text { length deviation }\end{array}$ & $\begin{array}{c}\text { Centromeric } \\
\text { index }\end{array}$ & $\begin{array}{c}\text { Chromosome } \\
\text { classification }\end{array}(2)$ \\
1 & $58.12 \pm 4.62$ & 26.22 & $54.60 \pm 5.30$ & 28.48 & sm \\
2 & $50.70 \pm 2.16$ & 27.21 & $50.21 \pm 4.58$ & 28.28 & sm \\
3 & $46.49 . \pm .2 .16$ & 28.17 & $46.81 . \pm .5 .54$ & 27.44 & $\mathrm{sm}$
\end{tabular}


Continue table 1

\begin{tabular}{|c|c|c|c|c|c|}
\hline \multicolumn{3}{|c|}{ Morelos population } & \multicolumn{3}{|c|}{ Michoacan population } \\
\hline $\begin{array}{l}\text { Chromosome } \\
\text { pairs }\end{array}$ & $\begin{array}{l}\text { Relative } \pm \text { standard } \\
\text { length deviation }\end{array}$ & $\begin{array}{l}\text { Centromeric } \\
\text { index }_{(1)}\end{array}$ & $\begin{array}{l}\text { Relative } \pm \text { standard } \\
\text { length deviation }\end{array}$ & $\begin{array}{l}\text { Centromeric } \\
\text { index }_{(1)}\end{array}$ & $\begin{array}{l}\text { Chromosome } \\
\text { classification } \\
(2)\end{array}$ \\
\hline 4 & $42.77 \pm 1.51$ & 29.28 & $40.10 \pm 5.11$ & 30.49 & $\mathrm{sm}$ \\
\hline 5 & $51.91 \pm 4.88$ & & $54.92 \pm 3.95$ & & stt \\
\hline 6 & $47.80 \pm 2.19$ & & $47.76 \pm 2.78$ & & stt \\
\hline 7 & $47.82 \pm 2.83$ & & $47.59 \pm 1.98$ & & stt \\
\hline 8 & $45.83 \pm 1.70$ & & $45.66 \pm 2.57$ & & stt \\
\hline 9 & $44.92 \pm 2.93$ & & $46.94 \pm 2.12$ & & stt \\
\hline 10 & $44.25 \pm 1.45$ & & $45.19 \pm 2.82$ & & stt \\
\hline 11 & $43.40 \pm 2.01$ & & $44.25 \pm 2.66$ & & stt \\
\hline 12 & $43.14 \pm 1.65$ & & $43.26 \pm 1.77$ & & stt \\
\hline 13 & $41.58 \pm 1.42$ & & $42.02 \pm 2.07$ & & stt \\
\hline 14 & $41.13 \pm 1.53$ & & $40.74 \pm 2.11$ & & stt \\
\hline 15 & $40.38 \pm 1.12$ & & $40.14 \pm 2.16$ & & stt \\
\hline 16 & $39.43 \pm 1.29$ & & $39.14 \pm 2.51$ & & stt \\
\hline 17 & $38.64 \pm 1.03$ & & $37.98 \pm 2.47$ & & stt \\
\hline 18 & $37.78 \pm 1.31$ & & $37.05 \pm 2.39$ & & stt \\
\hline 19 & $37.00 \pm 1.74$ & & $36.62 \pm 2.39$ & & stt \\
\hline 20 & $36.42 \pm 1.71$ & & $35.27 \pm 1.94$ & & stt \\
\hline 21 & $33.76 \pm 0.67$ & & $34.06 \pm 2.28$ & & $s t t$ \\
\hline 22 & $32.04 \pm 1.82$ & & $32.48 \pm 3.10$ & & stt \\
\hline 23 & $28.91 \pm 1.81$ & & $29.74 \pm 2.38$ & & stt \\
\hline 24 & $25.76 \pm 3.09$ & & $27.48 \pm 1.74$ & & stt \\
\hline
\end{tabular}

(1) $\mathrm{CI}=$ Centromeric index $=$ length of the short arm/total length

(2) according to Levan et al. (1964)

\section{DISCUSSION}

The karyotypes of the $C$. istlanum populations of the rivers Amacuzac (Morelos) and Huámito (Michoacán) have a common complement of $2 n=48$. The assumption that no chromosomal change has occurred is supported by the coincidence in the number of submetacentric and subtelo-acrocentric chromosomes and in the centromere position of the submetacentrics, by the lack of significant differences in chromosome lengths, as well as by an overall similarity of their G-banding patterns. Alternatively, it could also be considered that actual modifications could be too small to be detected by the methodology followed in this work. The assumption of populational chromosome divergence between the populations would be based on frail evidence.
G-band studies in fishes have been limited (Hartley \& Thorne 1985, Gold et al. 1990) because, for reasons probably related to intrinsic chromosome structure or to their size, do not show the abundance nor the resolution found in other animal groups, like mammals, particularly when the chromosome material has been obtained through direct techniques, but for a few exceptional cases (e.g. Sola et al. 1984). In this study, the agreement in the Gbanding patterns of both populations supports the lack of chromosome diversification and, hence, of population divergence.

The morphometric analyses performed by Bonilla-Ruz (1982) and by Sánchez-Salazar (1984) detected overlapping in the characters that, according to De Buen (1946), were distinctive of the two proposed subspecies. These analyses agree with the results of this study in 
that not enough differences were found to substantiate the subdivision of $C$. istlanum. The absence of population diversification, as estimated through chromosome and morphometric analyses, might have been brought about by an abated geographic isolation due to gene flow among contiguous populations along their continuous distribution in the Balsas Basin regions, by the relatively small divergence time since their distribution in these regions and/or, less probably, by a recent historical replacement of one population by the other, event of which there is no evidence.

The number of biarmed chromosomes of the Cichlasoma species has been related to their presumed geographic radiation center: the species considered to be of Central American origin, such as $C$. istlanum, $C$. beani (Jordan, 1888), C. labridens (Pellegrin, 1903) and $C$. managuense (Günther, 1862) (Regan, 1906-1908) (Thompson 1979, Salas \& Boza 1991) have a smaller number of metacentric chromosomes than those of South American affinity, which show more metacentrics, except for some species, such as $C$. bimaculatum (L. 1758) and $C$. severum (Heckel, 1840), which show a smaller number, mainly through robertsonian rearrangements and pericentric inversions (Thompson 1979).

The diploid chromosome number of $C$. istlanum $(2 \mathrm{n}=48)$ agrees with that of practically all the Cichlasoma species studied. According to the classification proposed by Thompson (1979), based on the number of biarmed chromosomes, the karyotype of $C$. istlanum is type " $\mathrm{A}$ " since it has less than five meta-submetacentric chromosomes, differing from the karyotypes " $\mathrm{B}$ " that have five or more meta-submetacentric chromosome pairs. The common occurrence of karyotype " $A$ " in some species is no evidence of a close phylogenetic relationship among them because, although they share this karyotype configuration, they belong to different species groups of the genus Cichlasoma (Regan 1905, Miller \& Nelson 1961, Miller, 1966). If the classification method of Levan et al. (1964) is followed, the karyotype of $C$. istlanum is coincident with those of $C$. dovii (Günther, 1864) (Thompson, 1979, Salas \& Boza, 1991), C. citrinellum (Günther, 1864), C. festivum (Heckel, 1840) (Thompson 1979), C. trimaculatum (Günther, 1866) (Uribe-Alcocer et al. 1992), C. managuense (Salas \& Boza 1991) and C. facetum (Jenyns, 1842) (Feldberg \& Bertollo 1985). Furthermore, these species not only belong to different species groups, but some of them have also been considered to belong to the South American groups while others have been considered to have Central American affinities.

Kornfield et al. (1979), Thompson (1979), Vervoort (1980) and Uribe-Alcocer \& Arreguín-Espinosa (1989) have pointed out that some cichlid species, close or distant phylogenetically, do not show large karyotype differences. Existent variability might be due to the acquisition or loss of small chromosome fragments, to non-reciprocal translocations, to pericentric inversions, and to tandem duplications or differential crossing-overs (Uribe-Alcocer et al. 1992). It is not likely that these rearrangements have been relevant to their evolution, since changes in the structure or size of chromosomes have not modified the diploid nor the fundamental chromosome numbers of their populations and, for this reason, their reproductive isolation has been probably brought about by other means. Notwithstanding some reports of chromosome variability in cichlid species (Feldberg \& Bertollo 1984, Salas \& Boza 1991), which justified the search undertaken in this study, the karyotype in this genus seems to be a conservative feature of low modification rate that apparently accompanies the evolution of the species, but does not bring about their reproductive isolation, nor the evolution of other biological characters. The widespread absence of significant karyotype differences in the genus Cichlasoma might also be attributed to characteristics inherent to the genome organization still to be identified and understood.

Genetic studies of the neotropical cichlids by methodologies that allow the detection of existing variations, for instance in their allozymes, their DNA (Sültmann et al. 1995), 
or in their microsatellite markers (Lee \& Kocher 1996), are considered necessary to establish, confirm or modify our knowledge of the phylletic relationships of this important group of neotropical cichlids.

\section{ACKNOWLEDGMENTS}

The authors are grateful to Néstor Valdés Morales, Topiltzin Contreras -McBeath, Jorge Luna Hernández, Yolanda Hornelas-Orozco, Lourdes Barbosa and Mónica DomínguezLópez for their valuable help in different aspects of this study.

\section{RESUMEN}

Cichlasoma istlanum (Jordan \& Snyder, 1900) es un cíclido dulceacuícola que se encuentra en la provincia del Río Balsas en la Cuenca del Pacífico mexicano. De Buen (1946), basado en caracteres merísticos de la especie, propuso la división en dos subespecies: $C$. istlana istlana, procedente del Río Ixtla, en el estado de Morelos, y $C$. istlana fusca, del Río Huámito, Michoacán. En este trabajo se estableció el cariotipo de la especie por medio de procedimientos citogenéticos convencionales y de bandeo $\mathrm{G}$, y se realizó un análisis comparativo de los cariotipos provenientes de las muestras de las dos poblaciones previamente propuestas como subespecies. Se recolectaron diez hembras en el Río Amacuzac, en el estado de Morelos, y nueve especímenes en el Río Huámito: dos hembras y siete machos. Mediante la cuenta de 264 campos mitóticos de la primera muestra y 203 de la segunda, se pudo establecer un número modal de $2 \mathrm{n}=48$ en cada una, moda que se consideró correspondía al número diploide de la especie. El análisis cariotípico se basó en diez cariogramas preparados de la población de Morelos y de ocho de la de Michoacán, que incluyó tres provenientes de hembras y cinco de machos. La fórmula cromosómica encontrada fue de $8 \mathrm{sm}+40 \mathrm{stt}$. El patrón de bandas $\mathrm{G}$ de ambas poblaciones fue similar y las comparaciones estadísticas de las longitudes promedio de los pares cromosómicos no mostraron diferencias significativas concluyentes entre ambas poblaciones. La existencia de un cariotipo prácticamente idéntico concuerda con la falta de diversificación subespecífica entre las poblaciones estudiadas. Los análisis morfométricos realizados por otros autores que encontraron sobreposición en los caracteres que fueron propuestos como distintivos de las dos subespecies, concuerdan con los resultados del presente estudio en que no se detectó divergencia suficiente para fundamentar la subdivisión de
C. istlanum. La falta de divergencia poblacional encontrada puede deberse a un aislamiento geográfico disminuído por la existencia de flujo genético entre poblaciones contiguas a lo largo de su distribución en las diferentes regiones del Río Balsas, por un lapso de divergencia evolutiva relativamente corto a partir de su distribución en estas regiones $y / o$, con menor probabilidad, por un reemplazo de una población por la otra. La estabilidad carotípica encontrada pueda ser debida también a características, aun por identificarse y definirse, inherentes a la organización del genoma en este género.

\section{REFERENCES}

Alvarez del Villar, J. 1970. Peces mexicanos. Serie Investigación Pesquera. Est. No. 1. Inst. Nal. de Inv. Biol. Pes., p. 1-166.

Alvarez del Villar, J. 1972a. Algunos ejemplos de especiación en peces mexicanos. Acta Politécnica Mexicana 13: 72- 81 .

Alvarez del Villar, J. 1972b. Ictiología mexicana V. Origen y distribución de la ictiofauna dulceacuícola de Michoacán. An. Esc. Nal. Cienc. Biol., Méx. 19: 155-161.

Alvarez del Villar, J. 1977. Relación entre la geomorfología mesoamericana y la distribución actual de los peces. Bol. Inst. Geología Univ. Nal. Autón. México 101: 182-192.

Amores, A., V. Giles, G. Thode \& C. Alvarez. 1990. Adaptive character of a Robertsonian fusion in chromosomes of the fish Gobius paganellus (Pisces, Perciformes). Heredity 65: 151-155.

Arredondo-Figueroa, J.L. \& M. Guzmán-Arroyo. 1986. Situación taxonómica actual de las especies de la tribu Tilapiini (Pisces, Cichlidae) introducidas en México. An. Inst. Biol. Univ. Nal. Autón. México 56, Ser.Zoología 56: 555-572.

Bonilla-Ruz, C.R. 1982. Contribución al conocimiento de la ictiofauna de la Cuenca del Balsas, en el este del Estado de Michoacán. Tesis de Licenciatura. Instituto Politécnico Nacional, México, D.F.

Contreras-McBeath, T. 1997. Cichlasoma (Parapetenia) istlanum vs. Cichlasoma (Archocentrus) nigrofasciatum, evidencia directa de competencia reproductiva. XIV Congreso Nacional de Zoología. Sociedad Mexicana de Zoología, Guanajuato, México. p. 28.

Cruz-Gómez, A. \& A. Rodríguez-Varela. 1997. Crecimiento de Cichlasoma urophthalmus en condiciones de 
laboratorio y notas sobre su reproducción. XIV Congreso Nacional de Zoología. Sociedad Mexicana de Zoología, Guanajuato, México.p. 30.

De Buen, F. 1946. Ictiogeografía continental mexicana. Rev. Soc. Mex. Hist. Nat. 7: 87-138.

Feldberg, E. \& L.A.C. Bertollo. 1984. Discordance in chromosome number among somatic and gonadal tissue cells of Gymnogeophagus balzanii (Pisces, Cichlidae). Rev. Brasil. Genet. 7: 639-645.

Feldberg, E. \& L.A.C. Bertollo. 1985. Karyotypes of ten species of Neotropical Cichlids (Pisces, Perciformes). Caryologia 38: 257-268.

Foresti, F., F. De Almeida-Toledo \& S. De AlmeidaToledo. 1984. Chromosomes studies in Gymnotus carapo and Gymnotus sp. (Pisces, Gymnotidae). Caryologia 37: 141-146.

García, M.I.J. 1993. Fauna helmintológica de Chichlasoma fenestratum (Pisces: Cichlidae) de lago de Catemaco, Veracruz, México. An. Inst. Biol. Univ. Nac. Autón. México 64, Ser. Zoologia: 75-78.

Gold, J.R., Y.C. Li, N.S. Shipley \& P.K. Powers. 1990. Improved methods for working with fish chromosomes with a review of metaphase chromosome banding. J. Fish Biol. 37: 563-575.

Hartley, S.E. \& M.T. Thorne. 1985. Cytogenetic techniques in fish genetics. J. Fish Biol. 26: 575-582.

Jordan, S. \& J. Snyder. 1900. Notes of collection of the fishes from the rivers of México, with description of twenty new species. Bull. U. S. Fish. Comm. 19: 115-147.

Kornfield, I.L, V. Ritte, C. Richler \& J. Wahrman. 1979. Biochemical and cytological differentiation among cichlid fishes of the Sea of Galilee. Evolution 33: 1-14.

Lamothe-Argumedo, R. \& M.L. Aguirre-Macedo. 1991. Metacercaria de Echinochasmus zubedakhaname, parásito de Cichlasoma urophtalmus en Celestún, Yucatán, México. An. Inst. Biol. Univ. Nac. Auton. México 62, Ser. Zoología: 139-140.

Lee A.J. \& T.D. Kocher. 1996. Microsatellite DNA markers for genetic mapping in Oreochromis niloticus. J. Fish Biol. 49: 169-171.

LeGrande, W.H. 1981. Chromosomal evolution in North American catfishes (Siluriformes; Ictaluridae) with particular emphasis on the madtoms, Noturus. Copeia 1981: 33-52.
Levan, A.K., A. Fredga \& R. Sandberg. 1964. Nomenclature for centromeric position of chromosomes. Hereditas 52: 201-220.

Luna-Figueroa, J. \& J. Figueroa-Torres. 1997. Crecimiento en cautiverio de Cichlasoma istlanum (Pisces: Cichlidae). XIV Congreso Nacional de Zoología. Sociedad Mexicana de Zoología, Guanajuato, México. p. 75 .

Maldonado-Monroy, M.C., M. Uribe-Alcocer, J. ArreguínEspinosa \& A. Castro-Pérez. 1985. Karyotypical studies on Dormitator maculatus Bloch and Gobiomorus dormitor Lacepède (Gobiidae: Perciformes). Cytologia 50: 15-21.

Martínez-Palacios, C.A., C. Chávez-Sánchez \& M.A. Olvera Novoa. 1993. The potential for culture of the American Cichlidae with emphasis on Cichlasoma urophthalmus. p. 195-232. In J. F Muir, \& R.J. Roberts (eds.). Recent advances in aquaculture. Vol. 4., Blackwell, Oxford, England.

Martínez-Palacios, C.A. \& L.G.Ross. 1992. The reproductive biology and growth of the Central American cichlid Cichlasoma urophthalmus (Guenther). J. Appl. Ichthyol./Z. Angew. Ichthyol. 8: 99-10̉0.

Mejía-Mójica, H. 1997. Análisis sobre algunos caracteres osteológicos en el género Cichlasoma. XIV Congreso Nacional de Zoología. Sociedad Mexicana de Zoología, Guanajuato, México. p. 82.

Miller, R.R. 1966. Geographical distribution of Central American fresh water fishes. Copeia 1966: 773-802.

Miller, R.R. \& B.C. Nelson. 1961. Variation, life colors and ecology of Cichlasoma callolepis, a cichlid fish from southern Mexico, with a discussion of the Thorychthys species group. Occ. Pap. Mus. Zool., Univ. Mich. 622: 1-9.

Nelson, S.J. 1994. Fishes of the World. Wiley. New York.

Pauls, E. \& L.A.C. Bertollo. 1983. Evidence for a system of supernumerary chromosomes in Prochilodus scrofa Steindachner, 1881 (Pisces, Prochilodontidae). Caryologia 36: 307-314.

Regan, C.T. 1905. A revision of the fishes of the American cichlid genus Cichlasoma and of the allied genera. Ann. Mag. Nat. Hist., Ser. 7, 16: 60-77, 225-243, 316-346.

Regan, C.T. 1906-1908. Pisces. In: Biología Central Americana 8: 1-201. 
Ruiz-Carús, J.R. 1995. Estudios citogenéticos, electroforéticos y de ADN mitocondrial en la familia Gerreidae (Pisces) del Atlántico Tropical Occidental. Tesis Doctoral. Facultad de Ciencias, Universidad Nacional Autónoma de México, México, D.F.

Salas, E. \& J. Boza. 1991. Citotaxonomía comparativa de tres especies de Cichlasoma (Pisces: Cichlidae) de Costa Rica. Rev. Biol. Trop. 39: 219-224.

Sánchez-Salazar, M.E. 1984. Análisis de la distribución geografía y de algunos requerimientos ecológicos de los cíclidos mexicanos, (Pisces: Perciformes). Tesis de Licenciatura. Instituto Politécnico Nacional, México, D.F.

Sola, L., B. Camerini \& S. Cataudella. 1984. Cytogenetics of Atlantic eels: C- and G-banding, nucleolus organizer regions, and DNA content. Cytogenet. Cell Genet. 38: 206-210.

Sültmann, H., W.E. Mayer, F. Figueroa, H. Tichy \& J. Klein. 1995. Phylogenetic analysis of cichlid fishes using nuclear DNA markers. Mol. Biol. Evol. 12: 1033-1047.

Thompson, K.W., 1979. Cytotaxonomy of 41 species of neotropical cichlidae. Copeia 1979: 679-691.

Trujillo-Jiménez, P. 1995. Dieta y hábitos alimenticios de Cichlasoma nigrofasciatum (Pisces: Cichlidae) del Río Amacuzac, Morelos. XIII Congreso Nacional de
Zoología. Sociedad Mexicana de Zoología, Monterrey, México. p. 95.

Uribe-Alcocer, M. \& J. Arreguín-Espinosa. 1989. Los cromosomas de los peces Oreochromis urolepis hornorum y Oreochromis mossambicus (Pisces: Cichlidae). An. Inst. Cienc. del Mar y Limnol., Univ. Nal. Autón. México 16: 189-198.

Uribe-Alcocer, M., B.L. Náder-García \& N. ValdésMorales. 1992. The Chromosomes of two cichlids from Mexico Cichlasoma ellioti and C. trimaculatum. Jap. J. Ichthyol. 39: 174-177.

Uribe-Alcocer, M., J. Arreguín-Espinosa, A. Torres-Padilla \& A. Castro-Pérez. 1983. Los cromosomas de Dormitator latifrons (Pisces: Gobiidae). An. Inst. Cienc. del Mar y Limnol. Univ. Nal. Auton. México 10: 23-30.

Vega-Bravo, L. 1973. Estudio de la línea lateral de los cíclidos mexicanos. Tesis de Licenciatura. Escuela Nacional Ciencias Biológicas, Instituto Politécnico Nacional, México, D.F.

Vervoort, A. 1980. The karyotypes of seven species of Tilapia (Teleostei: Cichlidae). Cytologia 45: 651656.

Vitturi, R. \& E. Catalano. 1989. Multiple chromosome polymorphism in the gobiid fish Gobius niger jozo L. 1758 (Pisces, Gobiidae). Cytologia 54: 231-235. 